\title{
A STUDY ON THE CYPRESS VIADUCT COLLAPSE AND SEISMIC PERFORMANCE OF A RETROFITTED BENT
}

\author{
Hajime OHUCHI*, Takashi MATSUDA** \\ and Yozo GOTO***
}

\begin{abstract}
This paper describes numerical simulation studies on the bent collapse of the Cypress Viaduct during the Loma Prieta Earthquake and on the seismic performance of the same type bent retrofitted. The purpose of the 1st simulation is to identify bent damage due to ground conditions and structural types and that of the 2nd simulation is to estimate seismic performance of the retrofitted bent. Systematized analyses provided following conclusions : 1) Amplified ground motion was appropriately predicted based on the multiple reflection theory, 2) Finite element nonlinear analyses provided good agreement with test results both of pre-retrofitted and retrofitted bents, 3) Nonlinear dynamic response analyses provided quantitative explanation on the relationship between ground conditions, bent types and bent collapses and also ensured sufficient seismic safety of the retrofitted bent.
\end{abstract}

Keywords : collapse simulation, ground motion, nonlinear response

\section{INTRODUCTION}

Catastrophic collapse of the Cypress Viaduct at Loma Prieta Earthquake 1989, caused 41 fatalities and amount of economic losses in San Francisco Bay area. A great concern was concentrated on the engineering issue to be resolved with 48 bents collapse in the $1.2 \mathrm{~km}$ long part of I-880 at the Cypress section. In the U.S., comprehensive seismic design specification was provided after the 1971 San Fernando Earthquake. However a great number of bridges including the Cypress Viaduct, were constructed in 1950's and 1960's. As the results, seismic vulnerability of existing bridges and seismic strengthening method were urged to investigate and a number of experimental and analytical studies have been conducted including field tests with survived bents. In these backgrounds, this paper presents numerical simulation studies on the collapse of the Cypress Viaduct and on the seismic performance of the retrofitted bent against several earthquakes consistent with the current U.S. seismic design guideline. A rational prediction of the Cypress Viaduct collapse is believed to contribute in the future earthquake hazard mitigation practice. Also a prediction on the seismic performance of the retrofitted bent may provide effective information in promoting seismic strengthening program for similar type viaducts in California.

* Member of JSCE. Dr. Eng., Chief Res. Engr.

Tech. Research Inst. Obayashi Co. Ltd. (4-640

Shimokiyoto, Kiyose, Tokyo, Japan-204)

** Member of JSCE. M. Eng., Assist. Chief Research Engr.

*** Member of JSCE. M. Eng., Manager.

\section{GENERAL}

\section{(1) Damage Summary}

As reported in the JSCE Reconnaissance Report on the Loma Prieta Earthquake of Oct. 17, 1989'), the cause of bent damages is considered as deeply related with the underlying ground condition and the structure type. The Cypress north side section was on reclaimed soft soil, while the south side section on dense silty sand. In the north side, all the upper decks fell down onto lower decks except one span portion. On the other hand in the south side falling down of upper decks was prevented except about $150 \mathrm{~m}$ portion next to the north side.

The bent types are conceptually categolized into 3 structure types as shown in Fig. 1 due to location of pinned joint and bent-cap structural type, i.e. reinforced or prestressed concrete. B type bent was employed in many parts and all collapsed in the north side. Among five A type bents existed in the north side, two of them survived despite significant damages suffered. In the south end of north side, all the $C$ type bents also collapsed.

\section{(2) Objectives of Present Study}

Numerical simulations are classified into two phases, i.e. collapse simulation of existed bents and seismic performance simulation of a retrofitted bent as shown in Fig.2.

The objective of 1st simulation is to provide rational answer to the following two questions : Are bent collapse in the north side section and bent survival in the south side section predicted if considering different ground conditions? and do B and $\mathrm{C}$ type bents collapse and an A Type bent not collapse in the north side section? As shown in Fig.2, analytical studies for this simulation consist of 4 parts : (I) Dynamic response analysis of ground, 

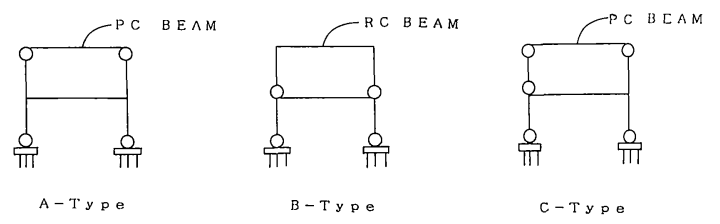

Fig.1 Bent Type-Conceptual Structure

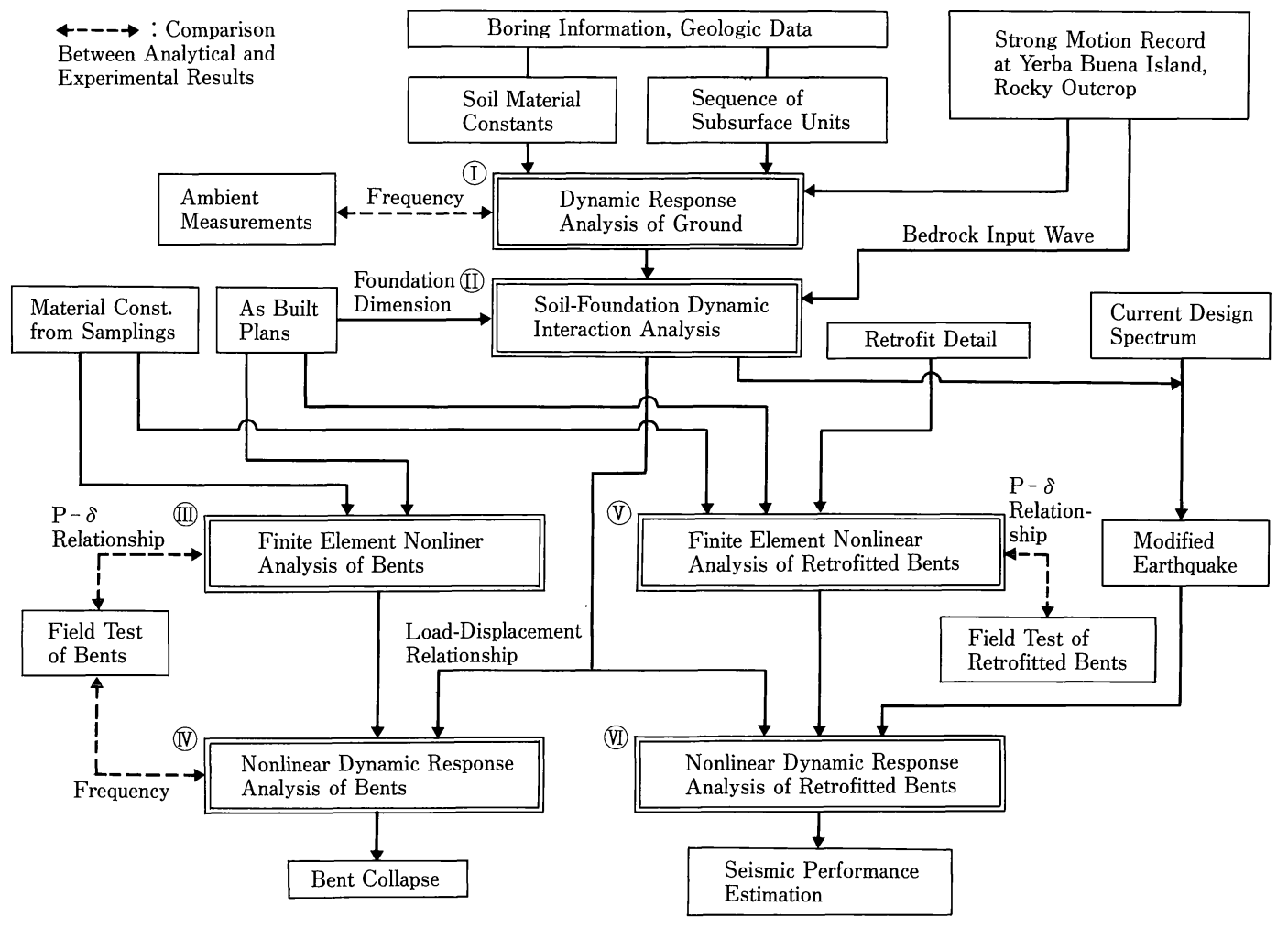

Phase-I Collapse Simulation of Existed Bents

Phase-II Seismic Performance Simulation of a Retrofitted Bent

Fig.2 Analytical Study Procedure

(II) Soil-foundation dynamic interaction analysis, (III) Static nonlinear analysis of bent and (IV) Nonlinear dynamic response analysis of bent. The objective of 2nd simulation is to provide similar rational answer to the following question : How much structural margin does the retrofitted bent possess against earthquakes with acceleration amplitude consistent with the current seismic design standard? As shown in Fig.2, analytical studies for this simulation consist of two parts : (V) Static nonlinear analysis of retrofitted bent and (VI) Nonlinear dynamic response analysis of retrofitted bent. Results from part (I) and (II) analyses are also utilized as an input motion and foundation characteristics for the part (VI) dynamic response analyses.

From the damage observation of survived bents and from the available accelerogram observed in the nearby site, the transverse motion of bridge axis is considered as dominant. Accordingly, all the above analyses are carried out against transverse motion of bridge axis neglecting structural contribution from the members parallel to the bridge longitudinal axis such as box girders except their gravity load.

\section{COLLAPSE SIMULATIONS}

\section{(1) Dynamic Response of Ground}

a) Analytical Method

A dynamic response analysis of a multi-layered ground is conducted based on the reflection theory. An equivalent linearization method is utilized to consider nonlinear behavior of soil material properties becasuse of comparatively small input acceleration of $0.035 \mathrm{G}$ from bedrock. Soil layers 
(A) North Side

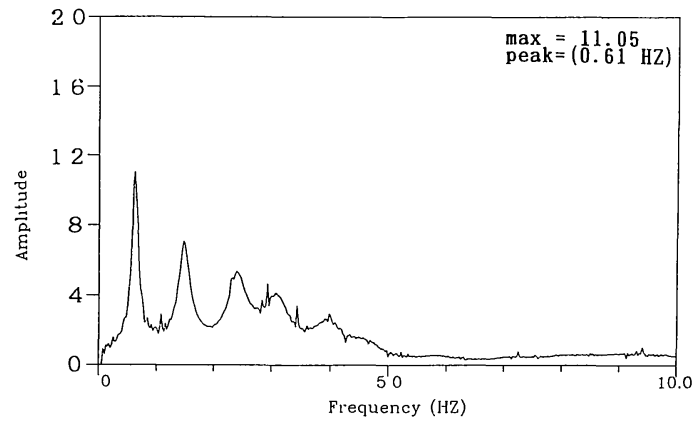

(B) South Side

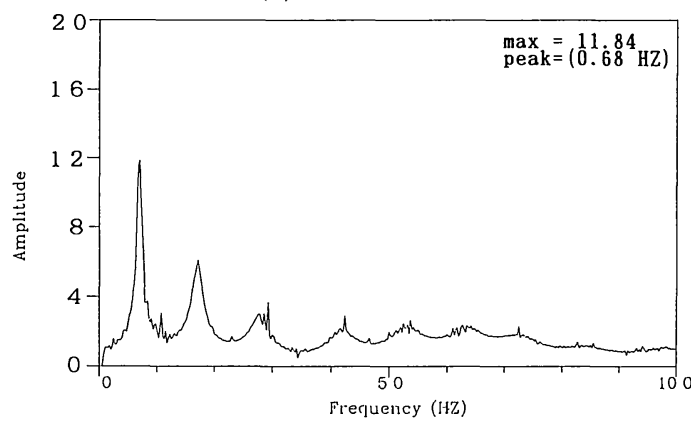

Fig.3 Calculated Transfer Function Between Bedrock and Ground Surface

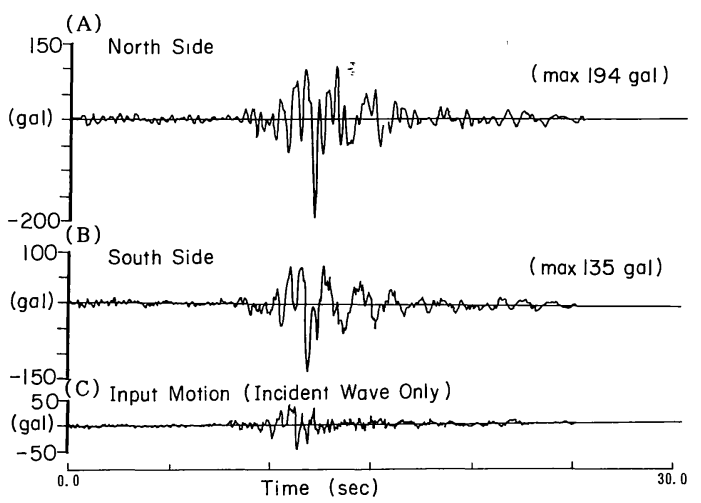

Fig.4 Ground Surface Acceleration Based on Multiple Reflection Theory

in the north side and south side sections are modelled on the basis of boring $\log$ datas $^{2)}$ and PS velocity logging datas ${ }^{3)-5)}$. A significant difference appears from the surface to $16.5 \mathrm{~m}$ depth below ground line (G.L.), i. e. soft bay mud from 2 to $6 \mathrm{~m}$ depth in the north side while dense silty sand from 4.5 to $16.5 \mathrm{~m}$ depth in the south side. An accelerogram recorded at Yerba Buena Island, rocky outcrop about $7 \mathrm{~km}$ distant from the Cypress Section (EW : 0.067 G, NS : $0.029 \mathrm{G}$ ) is employed as an input wave from bedrock. This island consists of Franciscan formation identical to the bedrock of
(A) South Side
(B) North Side

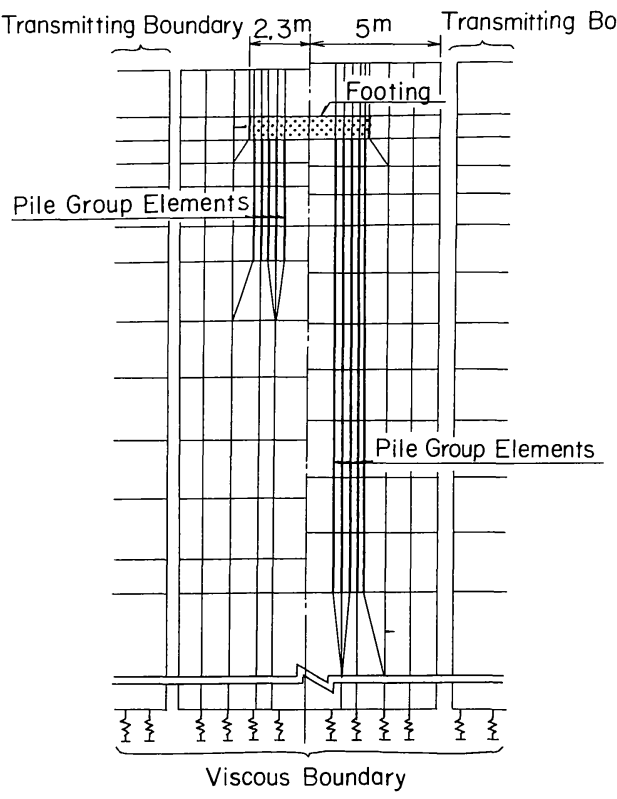

Fig.5 Axsymmetric Finite Element Models for Interaction Analysis

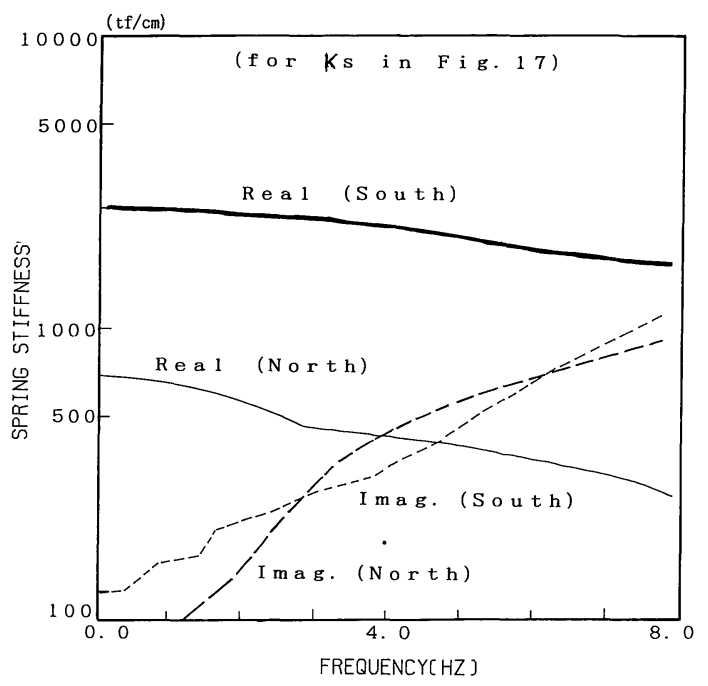

Fig.6 Frequency Dependent Characteristics of Spring

the Cyress Section. A half of EW component, is utilized as the incident wave from bedrock.

b) Analytical Results

Fig.3 illustrates the calculated transfer function between bedrock and ground surface, in which the first natural period predicted is respectively 0.61 and $0.68 \mathrm{~Hz}$ in each side and its amplification factor is nearly equal to each other, however the amplification in the higher frequency region $(1 \mathrm{~Hz}$ $\sim 4 \mathrm{~Hz}$ ) is larger in the north side than in the south side. The analytical period agrees fairly well with 


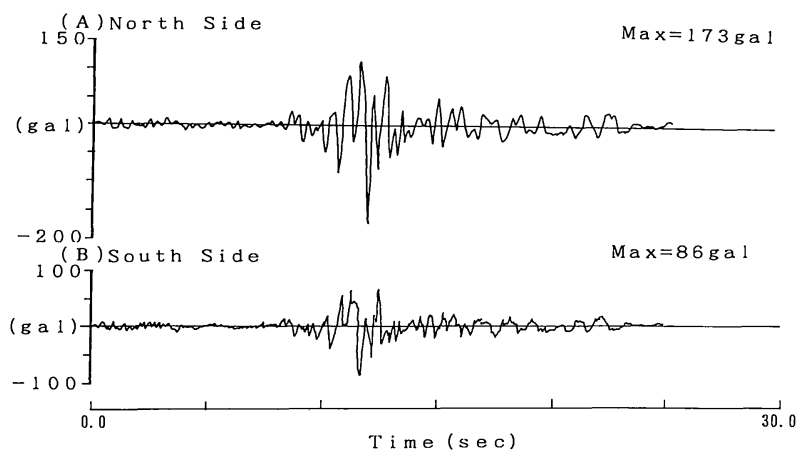

Fig.7 Effective Ground Surface Acceleration

the measured value of $0.7 \mathrm{~Hz}$ in the ambient vibration ${ }^{6}$. Fig. 4 illustrates the calculated ground surface acceleration waves with maximum accelerations of $194 \mathrm{gal}$ in the north side and of $135 \mathrm{gal}$ in the south side. In these analyses, the attained maximum shear strain of each layer is in the range of $6.5 \times 10^{-5} \sim 9.4 \times 10^{-5}$.

\section{(2) Soil-Foundation Dynamic Interaction}

a) Analytical Method

As a pair of bent columns stand on the independent foundation with each other, a unit of pile cap pile foundation system is idealized. Representative analytical bents to be discussed in this paper are No.96, 88 and 71 for A, B and C type bent respectively. An asymmeric dynamic response analysis is conducted with using axsymmetric finite elements as shown in Fig.5. The material characteristics of ground layers such as shear stiffness and damping are modelled by the results obtained in the previous ground response analysis. The nonlinear behavior such as slip between soil and foundation is neglected because no ground surface cracks suggesting significant slip were observed in the post-earthquake field investigation.

b) Analytical Results

The horizontal stiffness of the spring which corresponds to a model of the ground and an effective input acceleration on the top of pile cap are evaluated to be used for the three degrees of freedom system model as shown in Fig.17. Fig.6 illustrates frequency dependent characteristics of the spring analytically obtained from load-displacement relationship under horizontal harmonic excitation at the pile top. The real part corresponds to stiffness while the imaginary part damping characteristics. The real part for the south side provides about 3.5 times that for the north side.

The effective input motion which is required to take the kinematic interaction into account, is shown in Fig. 7. It is calculated by using axsymmetric finite element models shown in Fig.5 with input of the prescribed earthquake wave from the virtual
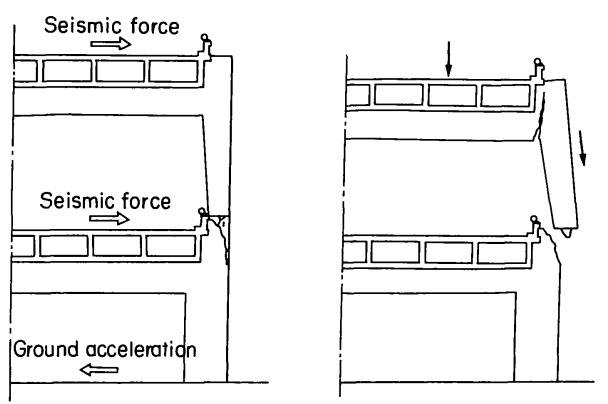

(A) Typical Failure Sequence of a B type Bent (Ref.9)

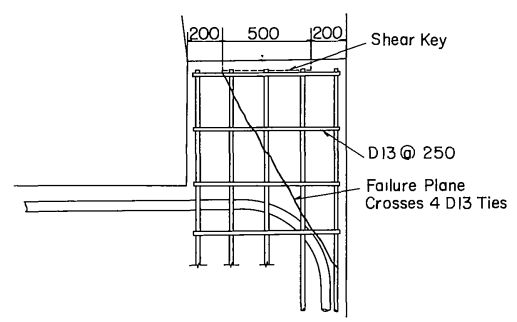

(B) A Shear Crack Along Bent Down Rebar in the Joint (Ref.9)

Fig.8 A Typical Bent Failure

bedrock.

(3) Static Nonlinear Behavior of Bents

A typical bent failure sequence ${ }^{7)}$ and an critical shear crack along bent down rebar in the joint are illustrated in Fig.8. The objectives in this section are to predict this critical shear failure and loaddisplacement relationships for the nonlinear dynamic response analysis in the following section. Caltrans conducted horizontal loading tests ${ }^{8) .9)}$ to estimate ultimate loading capacity of the existing bent (undestructive test) and to investigate seismic performance of the retrofitted bent (destructive test) with using the survived bent No.45-47 categorized as B type in the present study. The accuracy of present analyses will be verified through comparison with this nondestructive test result.

\section{a) Analytical Method}

Material constants are assumed as follows on the basis of the sampling test results and design informations ${ }^{8)}$ : for concrete, $f_{c}^{\prime}=443 \mathrm{kgf} / \mathrm{cm}^{2}, f_{t}=$ $7.5 \sqrt{6300} \mathrm{psi}=595 \mathrm{psi}=42 \mathrm{kgf} / \mathrm{cm}^{2}, E_{c}=2.8 \times$ $10^{5} \mathrm{kgf} / \mathrm{cm}^{2}$ and for steel reinfocement, $f_{y}=3032$ $\mathrm{kgf} / \mathrm{cm}^{2}$ (Grade 40 steel), $E_{s}=2 \times 10^{6} \mathrm{kgf} / \mathrm{cm}^{2}$. The case of tensile strength of $f_{t}=60 \mathrm{kgf} / \mathrm{cm}^{2}$ is additionaly analized to discuss the effect of material constant variation on the nonlinear behavior.

Two dimensional finite element nonlinear analyses are conducted with the concrete constitutive law proposed by Darwin and Pecknold ${ }^{10)}$. The 


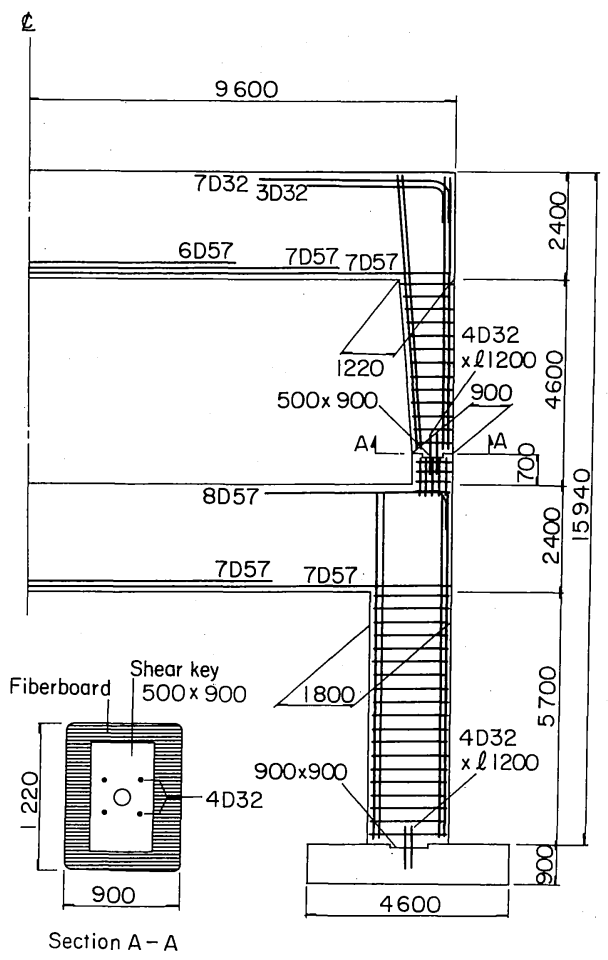

Fig.9 Dimention and Reinforcement Detail of B Type Bent-No.88 (Ref.11)

analytical structure is modelled into plane stress finite elements for concrete and truss elements for steel reinforcing bars except beam elements for four D32 (No.10) steel reinforcing bars in the pinned joints as shown in Fig.9 with assuming perfect bond between concrete and reinforcement. It is noted that tied hoops as shown in Fig.12, utilized for lateral confinement in the columns and pedestals, are modelled as continuous truss elements.

Multi layered reinforcements in the bent caps and columns are idealized as a single layer respectively in each internal and external location so that the ultimate moment capacity of idealized section is equivalent to that of original one.

The upper and the lower concrete parts through shear keys are assumed as monolithically connected except those through fiber board. No damage suffered in the past is also assumed with all bents.

After applying dead load, i.e. weight of bent caps and one span length box girder, static horizontal load uniformly distributed in each bent cap is increased. A horizontal load distribution on the height is determined based on the elastic first mode. Fig.9 illustrates dimension and steel reinforcement arrangements of the representative

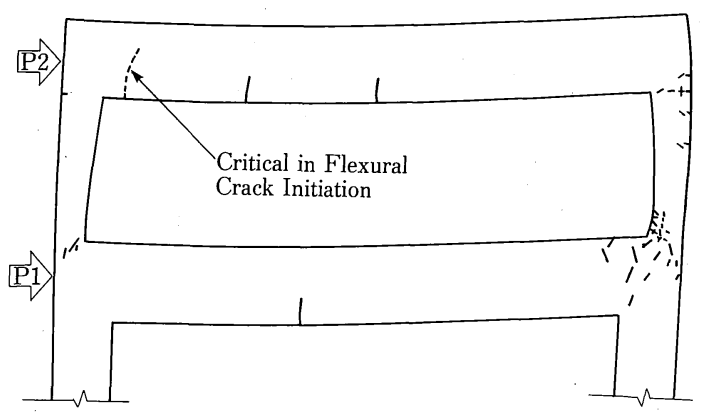

Fig.10 Crack Pattorn at Final Stage (B Type Bent)

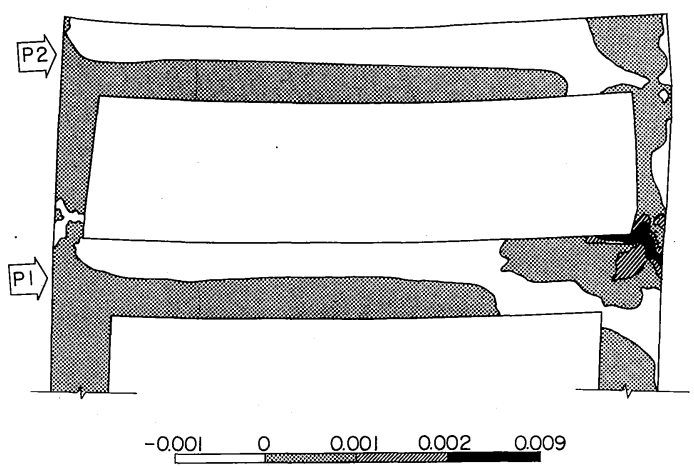

Fig.11 Horizontal Strain $\varepsilon_{x}$ Contour at Ultimate Stage (B Type Bent)

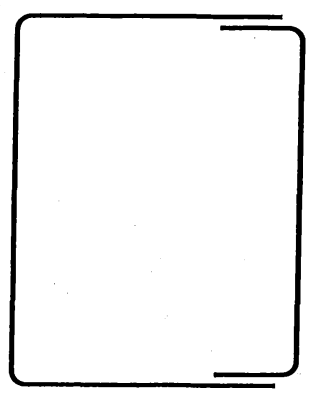

Fig.12 Configuration of Transverse Reinforcement in the Joint Region

bent (B type) $)^{11)}$.

b) Analytical Results

An ultimate crack pattern of $B$ type bent is illustrated in Fig.10. Even during dead load application, the shear crack initiates in the pedestal below the pinned joint of upper column due to shear force outward the joint. With horizontal load increasing, this crack propagates diagonally along bent down rebar in the joint and then vertically into concrete outer-coverage, which corresponds the failure mode illustrared in Fig.8. The left end of upper bent cap is critical in flexural crack shown as the broken line in Fig.10, which suggest the flexural crack concentration at upper bent cap end 


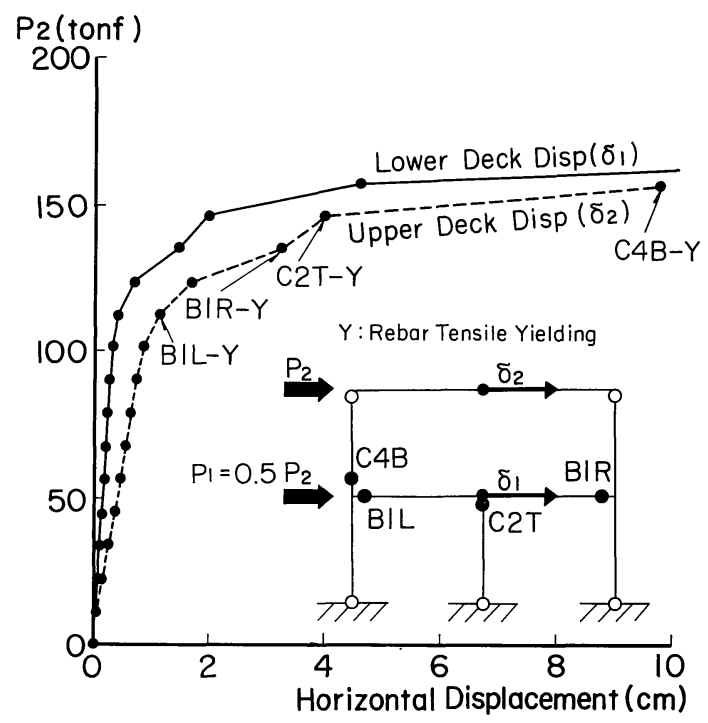

Fig.13 Load-Displacement Relationship (A Type Bent)

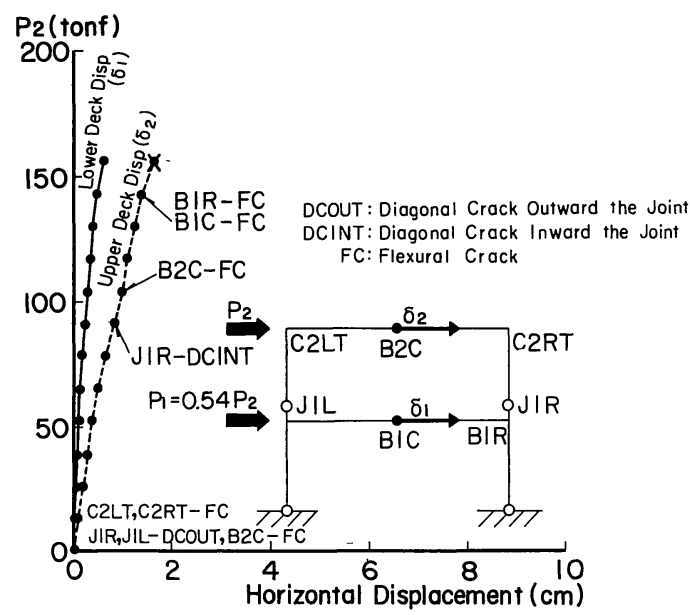

Fig.14 Load-Displacement Relationship (B Type Bent)

as shown in Fig.8 when considering insufficient anchorage of D57 (No.18) lower straight reinforcement (see Fig.9) and bond depression under cyclic horizontal load. Fig.11. illustrates horizontal strain contour of $\varepsilon_{x}$ at ultimate stage in which the strain concentration in the joint is to be comparable to the failure surface of Fig.8. When additionally considering less and insufficient shear reinforcement, i.e. tied hoop utilized as shown in Fig.12, this type of shear failure must be likely encouraged.

Horizontal load-displacement relationships for $\mathrm{A}, \mathrm{B}$ and $\mathrm{C}$ type bents are respectively shown in Fig.13 to 15. As shown in Fig.13, the analytical result predicts flexural yielding type failure in the $A$ type bent. In the B type bent, after the joint shear cracks extend to the concrete coverage, most of

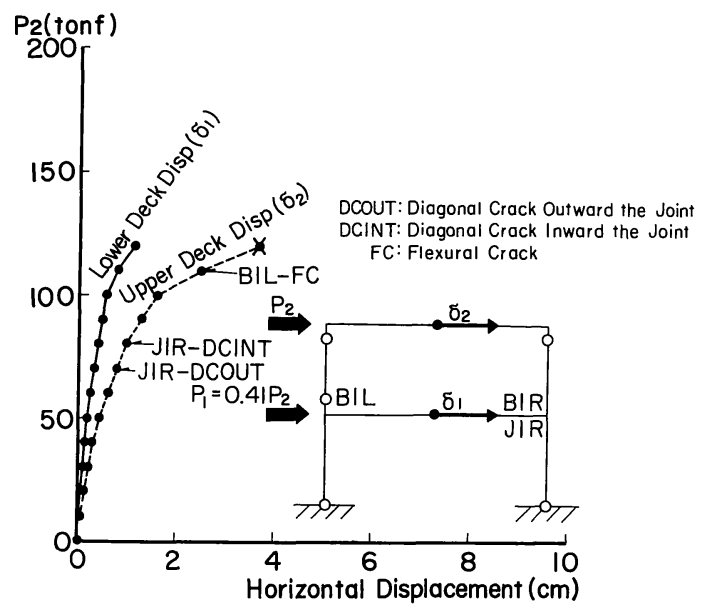

Fig.15 Load-Displacement Relationship (C Type Bent)

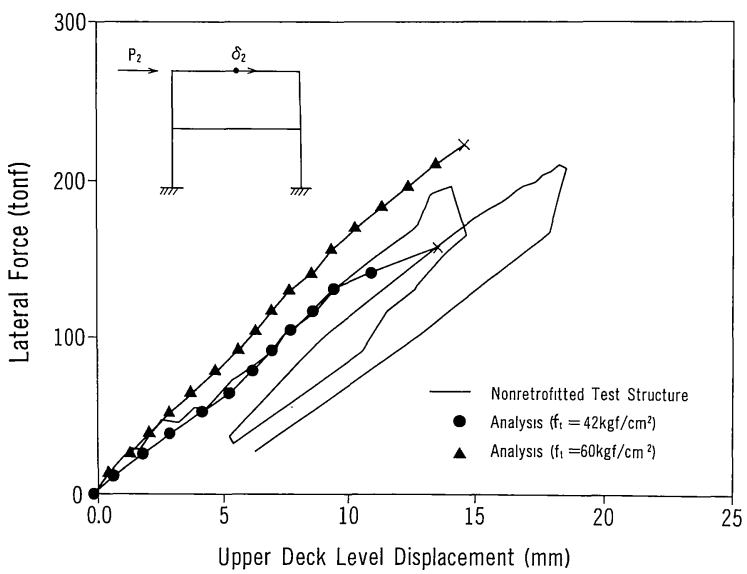

Fig.16 Load-Displacement Relationship (Bent No.46)

shear reinforcement in the pedestal ultimately yield. In the $\mathrm{C}$ type bent with pinned joints at both upper column tops, the shear crack initiates from pedestal to joint at relatively high horizontal load. However because one of upper columns resists no horizontal load, the lateral shear force concentrates on the other column, resulting in lower ultimate loading capacity and lower lateral stiffness obtained rather than the $B$ type bent.

The ultimate loading capacity of the B or C type bent is numerically determined by the load level when the internal lateral shear force in the critical column rapidly decrease umbalancing with the external horizontal load.

c) Comparison with Undestructive Test Results

In the field loading test, the horizontal load was applied only at the upper bent cap. Fig.16 illustrates load-displacement relationships where the analytical result $\left(f_{t}=42 \mathrm{kgf} / \mathrm{cm}^{2}\right)$ agrees with experimental result in the ascending part. The 


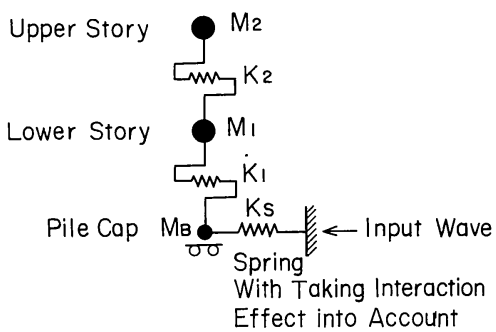

Fig.17 Three Degrees of Freedom System Model for Nonlinear Dynamic Response

predicted ultimate loading capacity is 156 tonf in comparison with 210 tonf in the experiment ${ }^{8)}$. Because ultimate load is deeply dependent on shear cracks in the joint, the case with concrete tensile strength of $f_{t}=60 \mathrm{kgf} / \mathrm{cm}^{2}$ is alternatively analized to discuss its influence. The larger but more approximate ultimate loading capacity with 234 tonf is obtained for this case. The stiffness difference between $f_{t}=42$ and $60 \mathrm{kgf} / \mathrm{cm}^{2}$ cases depends on the difference of crack growth especially during dead load application. When considering possible initial crack existence in the experimental bent, the tensile strength between these values may be more reasonable to use. However because of better prediction in stiffness, the case of $f_{t}=42$ $\mathrm{kgf} / \mathrm{cm}^{2}$ is employed in all the following analyses.

\section{(4) Nonlinear Dynamic Response of Bents}

a) Analytical Method

Nonlinear dynamic response analyses are conducted with using a three degrees of freedom system model including a spring taking soil-foundation interaction effect into account as shown in Fig.17. As for the enveloping curve of hysteresis models, shear force-relative displacements obtained from the finite element nonlinear analyses are idealized into tri-linear type model. As for the hysteretic rule, the flexural-failure-type degrading stiffness response model, so called Takeda model ${ }^{12)}$ is utilized for both upper and lower stories of the A type bent. In the B and C type bents, the similar model is utilized for the lower story, while the origin-orient hysteresis model for the upper story failed in brittle shear. Based on the dynamic interaction analysis in the section 3(2), the spring characteristics at base (Fig.17) is idealized as a linear elastic model with damping calculated considering strain energy for radiation damping. Superstructure damping is assumed as of $3 \%$.

b) Analytical Results

Table 1 shows elastic natural frequencies obtained from the three degrees of freedom system analyses. The analytical 1st natural frequency of $2.55 \mathrm{~Hz}$ agrees well with the forced vibration test
Table 1 Natural Frequency of Bents

\begin{tabular}{|c|c|c|c|}
\hline \multirow{2}{*}{$\begin{array}{c}\text { Structure } \\
\text { Type }\end{array}$} & \multirow[t]{2}{*}{ Site } & \multicolumn{2}{|c|}{ Frequency $(\mathrm{Hz})}$. \\
\hline & & $1 s t$ & $2 \mathrm{nd}$ \\
\hline \multirow{2}{*}{$\begin{array}{l}\text { A Type } \\
\text { (No.96) }\end{array}$} & North Side & 2.07 & 4. 99 \\
\hline & South Side & $2 \cdot 16$ & 5.21 \\
\hline \multirow{2}{*}{$\begin{array}{l}\text { B Type } \\
\text { (No.88) }\end{array}$} & North Side & 2.40 & 5.60 \\
\hline & South Side & $\begin{array}{c}2.55 \\
(2.50)^{*}\end{array}$ & $\begin{array}{c}6.25 \\
(4.50)^{*}\end{array}$ \\
\hline \multirow{2}{*}{$\begin{array}{l}\text { C Type } \\
\text { (No.71) }\end{array}$} & North Side & 2. 17 & 5.54 \\
\hline & South Side & $2: 31$ & 5. $7 \quad 1$ \\
\hline
\end{tabular}

( )* : Forced Vibration Test Results

result of $2.5 \mathrm{~Hz}^{7}$ for the $\mathrm{B}$ type bent. The obtained acceleration time histories and shear force-relative displacement hystresis in the critical upper story are tabulated in Table 2 in which characteristic responses can be identified due to bent types and ground conditions. In the north side $\mathrm{B}$ and $\mathrm{C}$ type bents, the upper story collapses immeadiately after the maximum ground surface acceleration. On the other hand in the south side, both type bents survive with some stiffness reduction appearance. The A type bent in the north side does not collapse with hysteretic damping effect due to flexural yielding. This analytical performance ensures survival of actual No.95 and No.96 bents despite considerable damages observed. It is considered that flexural yielding type hysteresis characteristics significantly contribute on preventing bent from catastrophic collapse.

\section{SEISMIC PERFORMANCE SIMULA- TION OF A RETROFITTED BENT}

\section{(1) Static Nonlinear Behavior of a Retrofitted Bent}

As described in the section 3.3, Caltrans conducted horizontal loading tests of retrofitted bents using survived No.45 to No. 47 bents with less damages. ${ }^{8)}$ After comparison with destructive test results to verify the accuracy, the analytical results for the following dynamic response analysis are to be discussed.

a) Analytical Method

The retrofitted No.46 bent ${ }^{13)}$, presently categorized as B type bent is analized in this chapter. The jacking forces with prestressing rods $(\phi 35 \mathrm{~mm}$ for bent cap flexural strengthening) are modelled by a pair of nodal forces and prestressing rods $\phi 35 \mathrm{~mm}$, $\phi 25 \mathrm{~mm}$ for column confinement and diagonal rock bolts in the beam column joint are respectively modelled as one of reinforcements. A Grade 40 steel is assumed for rock bolts and steel tubings to be combined with prestressing rods for column confinement.

Inadequate and insufficient anchorage effect of 
Table 2 Comparison of Bent Responses Between North Side and South Side

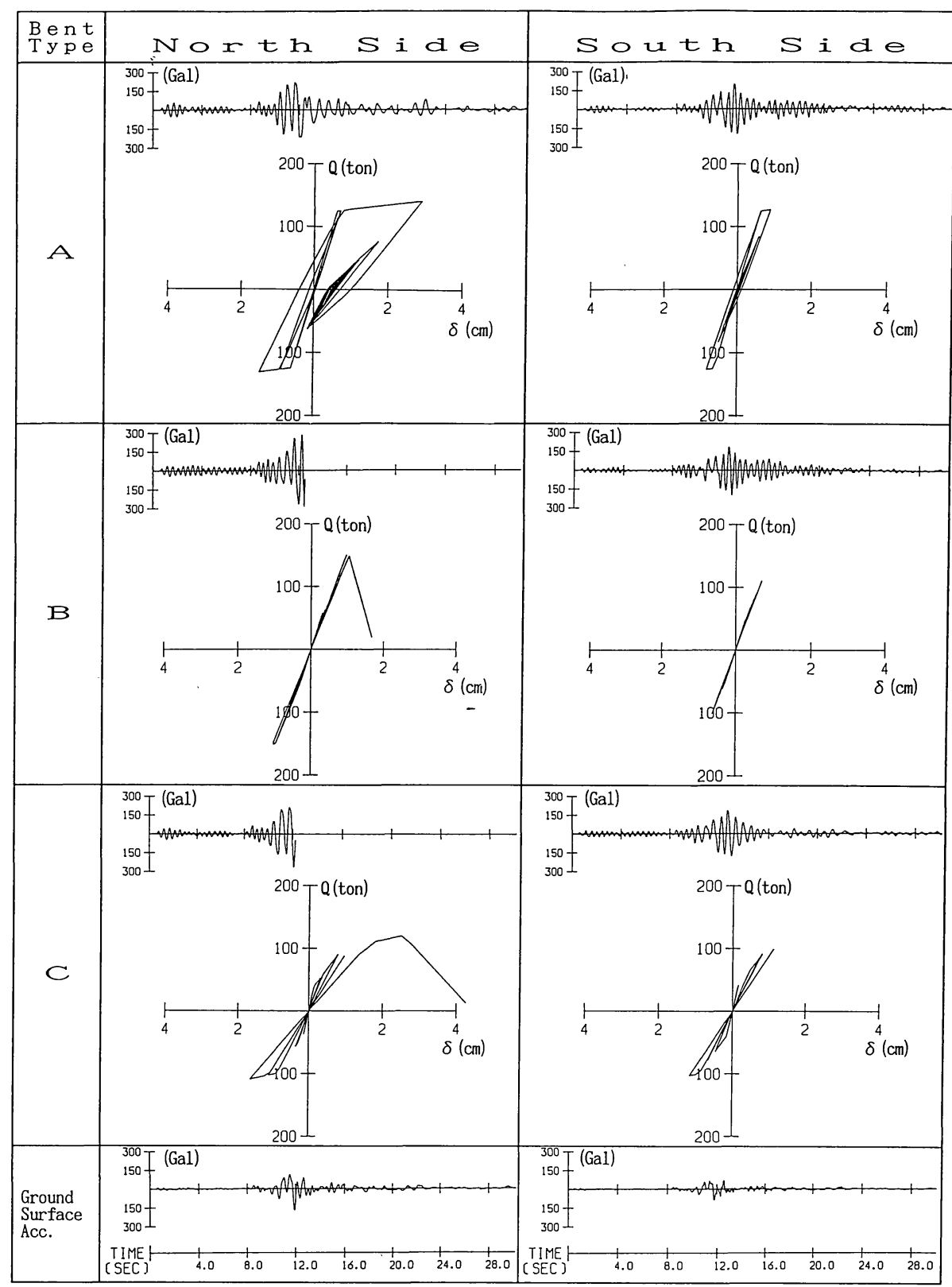

the bent cap lower reinforcement (D57) as described in the section 3(3) b), should be considered. The insufficient anchorage directed depression is modelled by reducing yielding strength of D57 rebar in the joints from $f_{s y}=3023 \mathrm{kgf} / \mathrm{cm}^{2}$ to $f_{s y}=f_{\text {slip }}=1890 \mathrm{kgf} / \mathrm{cm}^{2}$ based on the pull-out test results $^{14)}$ which provided the developed tensile stress - bar size relationship of reinforcing bar. Material constants and another assumption in the analysis are similar with those provided in the section 3(3). b) Analytical Results

A comparison between experimental and analytical load-displacement relationship in the destructive test is shown in Fig.18 to represent good approximation of a finite element nonlinear analysis. Analytical result in general ensure flexural type failure with fairly good agreement with experimental results.

Analytical load-displacement relationships, which are to be idealized for the hysteresis model in the following dynamic response analysis, are shown 


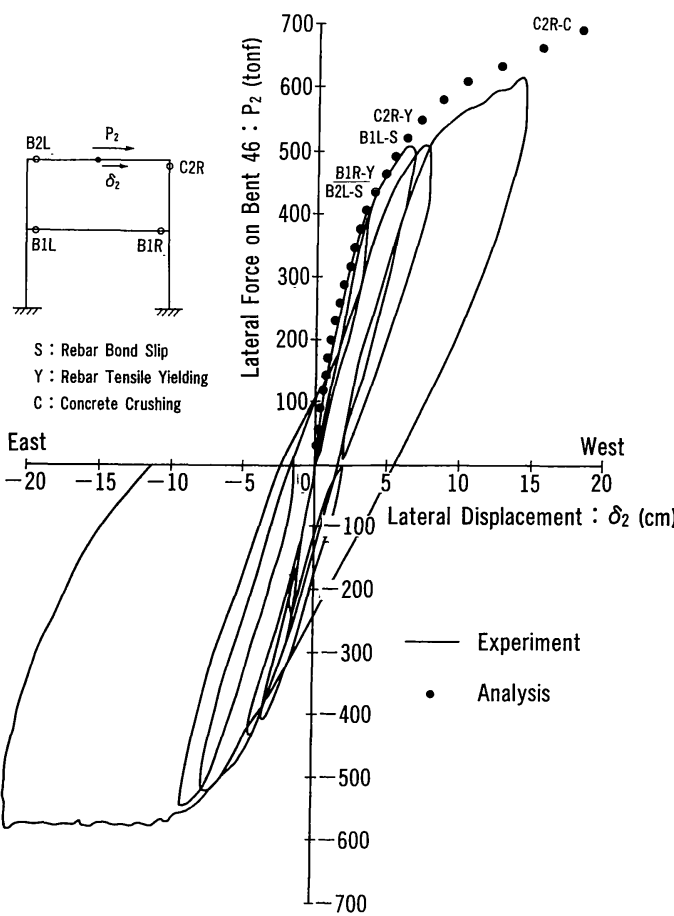

Fig.18 Load-Displacement Relationship (Retrofitted Bent No.46)

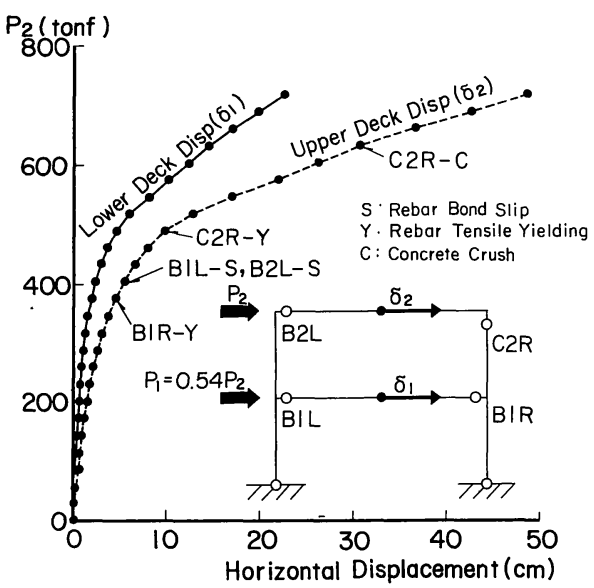

Fig.19 Load-Displacement Relationship (Retrofitted B Type Bent)

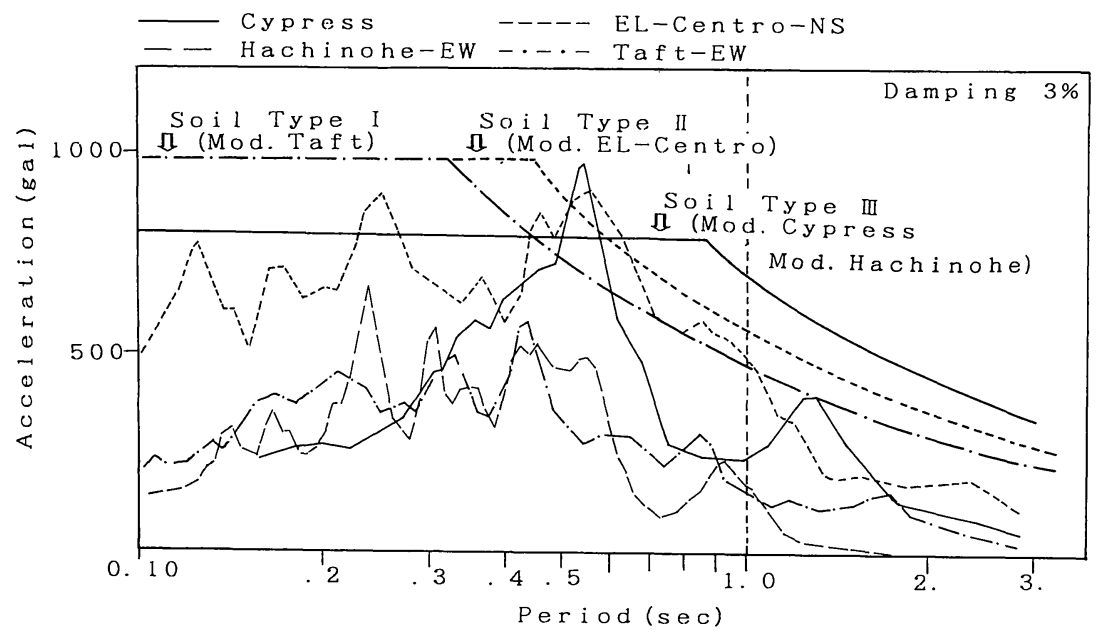

Fig.20 Elastic Acceleration Spectrum

in Fig.19. The analytical bent is the same as that compared with destructive test result. The locations of yield hinges produced are also completely same as that. However, they appear in about $10 \%$ earlier load stage because of loadings imposed on both upper and lower bent caps.

(2) Design Response Spectrum and Input Motion

Fig.20 illustrates elastic acceleration response spectrums by the previously predicted acceleration wave on the Cypress north side and the representative acceleration records in the past. The elastic seismic response spectrums for three soil types specified in the Seismic Design Guidline ${ }^{15)}$ are also shown. Design response fitted waves are respectively produced for 3 soil types by modifying acceleration amplitude of these waves with its phase angle unchanged. 
(A) Original Cypress

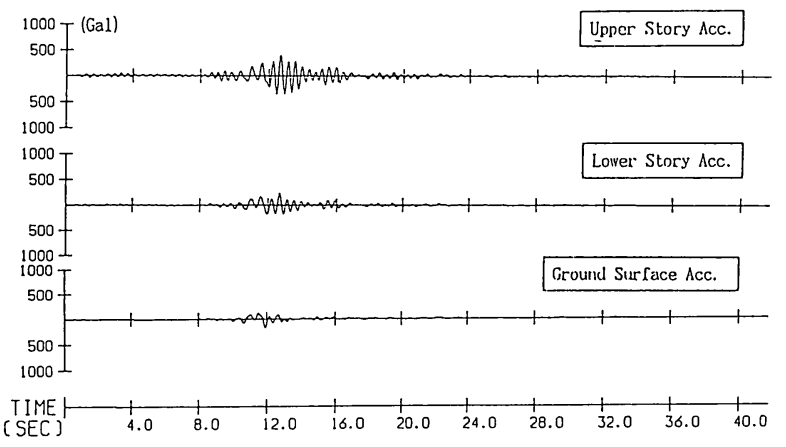

(B) Modified Hachinohe

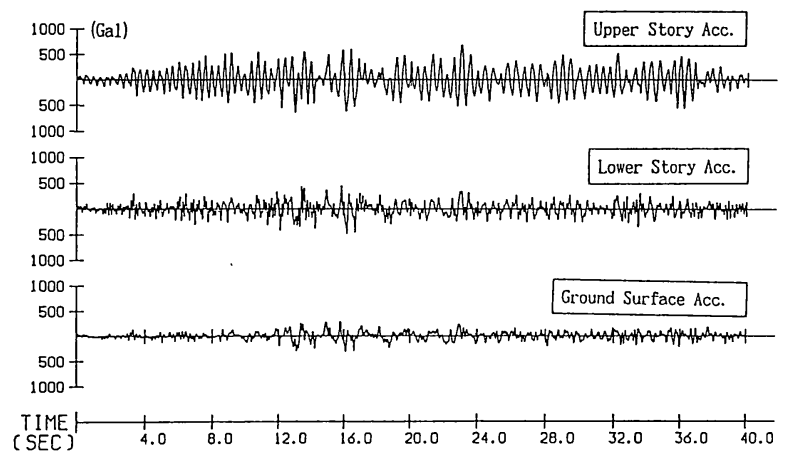

(C) Modified EL-Centro

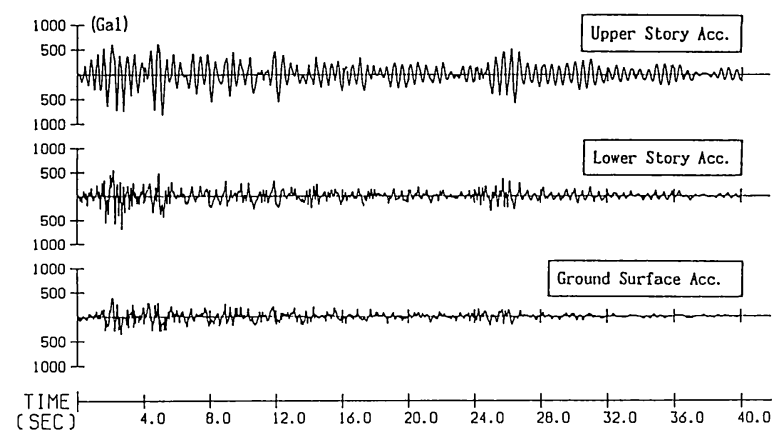

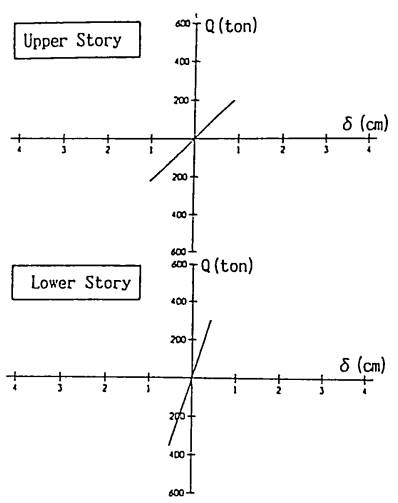
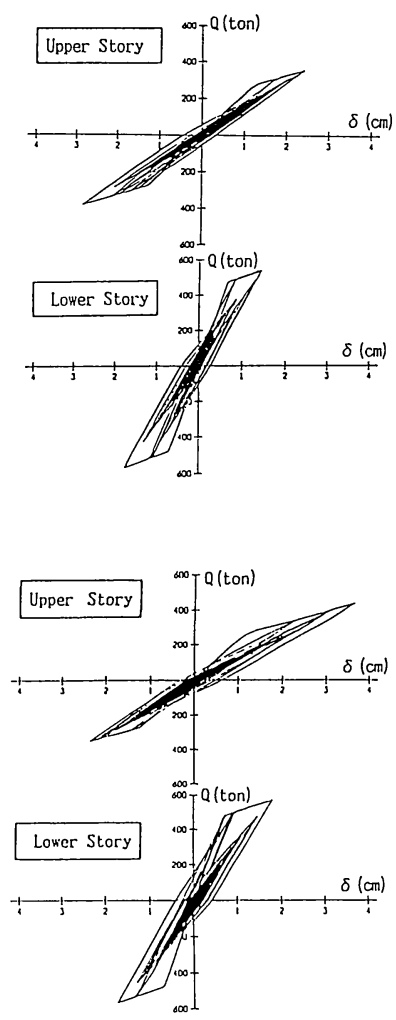

Fig.21 Seismic Response of Retrofitted Bent (B Type) - Acceleration Time History and Shear Force-Relative Displacement Hysteresis

(3) Nonlinear Dynamic Responses of A Retrofitted Bent

a) Analytical Method

A three degrees of freedom system model is used for both the Cypress wave and the modified Cypress wave, while a two degrees of freedom system model is used for another three modified waves because foundation and ground condition are not identified. The Takeda Model with trilinear type enveloping is also idealized for both upper and lower hysteresis characteristics in shear force-relative displacement relationship.

b) Analytical Results

Analytical results are represented in Fig.21. For the original Cypress wave, both upper and lower story responses remain in elastic. Except this case, the shear force reaches beyond elastic limit but not beyond yielding for any cases. The maximum response and the seismic performance evaluation in strength and ductility are provided in Table 3 for 
Table 3 Seismic Performance of a Retrofitted Bent

\begin{tabular}{|c|c|c|c|c|c|c|c|c|}
\hline \multirow[b]{2}{*}{$\begin{array}{l}\text { Input } \\
\text { Earthquake }\end{array}$} & \multirow[b]{2}{*}{ Story } & \multicolumn{2}{|c|}{ Input } & \multicolumn{3}{|c|}{ Response } & \multicolumn{2}{|c|}{ Safety Factor } \\
\hline & & $\begin{array}{c}y_{0 \max } \\
\text { Max. Vel. } \\
(\mathrm{cm} / \mathrm{sec})\end{array}$ & $\begin{array}{c}\ddot{y}_{0 \max } \\
\text { Max. Acc. } \\
\text { (gal) }\end{array}$ & $\begin{array}{c}\left(y_{0}+\delta\right)_{\max } \\
\text { Max. Acc. } \\
\text { (gal) }\end{array}$ & $\begin{array}{c}\delta_{\max } \\
\text { Max. Disp. } \\
(\mathrm{cm})\end{array}$ & \begin{tabular}{|}
$Q_{\max }$ \\
Max. Shear \\
Force (tf)
\end{tabular} & $\begin{array}{l}Q_{y} / Q_{\max } \\
\text { Strength }\end{array}$ & $\begin{array}{l}\delta_{u} / \delta_{\max } \\
\text { Ductility }\end{array}$ \\
\hline \multirow{2}{*}{ Cypress } & 2 & \multirow{2}{*}{24} & \multirow{2}{*}{173} & 398 & 1.00 & 222 & 2.23 & 16.30 \\
\hline & 1 & & & 221 & 0.51 & 352 & 2.13 & 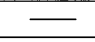 \\
\hline \multirow{2}{*}{ M. Cypress } & 2 & \multirow{2}{*}{68} & \multirow{2}{*}{345} & 635 & 2.33 & 349 & 1.42 & 7.00 \\
\hline & 1 & & & 397 & 1.28 & 527 & 1.42 & $\longrightarrow$ \\
\hline \multirow{2}{*}{ M. Hachinohe } & 2 & \multirow{2}{*}{49} & \multirow{2}{*}{310} & 680 & 2.84 & 383 & 1.29 & 5.74 \\
\hline & 1 & & & 481 & 1.75 & 567 & 1.32 & $\longrightarrow$ \\
\hline \multirow{2}{*}{ M. EL-Centro } & 2 & \multirow{2}{*}{47} & \multirow{2}{*}{383} & 810 & 3.65 & 437 & 1.13 & 4.47 \\
\hline & 1 & & & 685 & 1.80 & 571 & 1.31 & - \\
\hline \multirow{2}{*}{ M. Taft } & 2 & \multirow{2}{*}{52} & \multirow{2}{*}{386} & 729 & 3.04 & 396 & 1.25 & 5.36 \\
\hline & 1 & & & 491 & 1.52 & 547 & 1.37 & 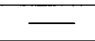 \\
\hline
\end{tabular}
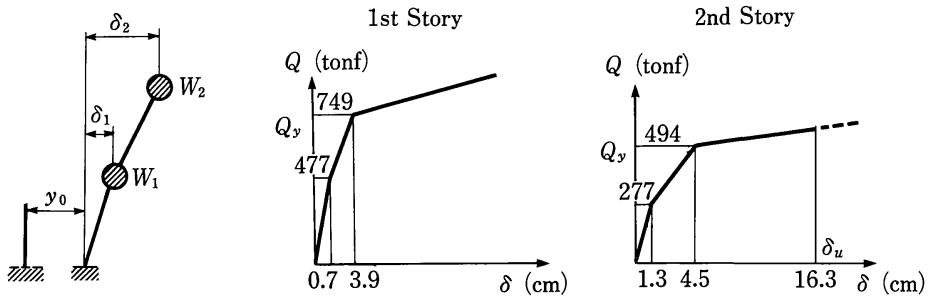

each input motion respectively, where the ultimate strength and the ultimate displacement are temporarily defined by the yielding shear force $Q_{y}$ and the relative displacement $\delta_{u}$ when concrete crush initiates at the upper story column top respectively. For all input waves, sufficient safety factor is assured in both strength and ductility. These results indicate that if the present type bent is strengthened in shear so that flexural-yielding-type performance be assured, sufficient margin in seisimic performance can be provided against not only the Loma Prieta earthquake but the input motions consistent with the current seismic design guideline as well.

\section{CONCLUDING REMARKS}

Based on the results presented, a number of conclusions can be summarized as follows :

1) The two dimensional finite element analyses predicted nonlinear behaviors of the existed bents and of the retrofitted bent up to the failure with good agreements in comparison with experimental results.

The analyses of existed B and C type bents predicted final shear failure from the pedestal to the bent cap-column joint with yielding of insufficient shear reinforcement and also suggested flexural crack concentration at the end of second story bent cap due to inadequate anchorage length of longitudinal reinforcement, those of which corresponds with the damages observed in the site.
On the other hand, the analysis of retrofitted bent provided good agreement with experimental results, especially taking the effect of insufficient anchorage length of longitudinal reinforcement of bent cap into account by temporarily idealizing its yield strength reduced.

2) The multi degrees of freedom system nonlinear response analysis, on the basis of systematized analyses, i.e. on the amplified ground motion, on the soil-foundation interaction and on the nonlinear behavior of the bents up to the ultimate, provided rational explanation for the sequential collapse scenario of the Cypress Viaduct.

With good correspondence to the damages observed in the site, it was predicted that an A type bent in the north side survived due to its ductile flexural yielding behavior and both $\mathrm{B}$ and $\mathrm{C}$ type bents in the north side collapsed in shear, while those in the south side survived due to little less amplified ground motion.

For the deficiency of observed acceleration records in the Cypress Section, it can not directly verify the accuracy of the calculated ground motion in the present procedure. However, it should be noted that the different damages of bents between the north and the south sides were appropriately lead due to the different input motions predicted. Namely, the present procedure with considering SH wave input, nonlinear material characteristics of soils and soil-foundation interaction, would be 
effective to provide a precise effective input motion for a simplified dynamic interaction model.

3) The present type of bent retrofitted mainly in shear provides sufficient seismic performance against input motions with acceleration amplitude consistent with the current seismic design guideline.

4) The collapse of the Cypress Viaduct is unlikely to provide effective lessons to the current seismic design practice in Japan because of the unusual structural feature with less redundancy and inadequate and insufficient reinforcement detail. In recent years, neverthless, a number of existing bridge columns with inadequate reinforcement such as cut-off reinforcing bars in column midsection, are urged to be strengthened even in Japan. The present study hopefully suggests one of sophisticated method to evaluate seismic resistance of these existing structures with higer accuracy.

\section{ACKNOWLEDGEMENT}

Most of informations and refernces utilized in the present study are from California Department of Transportation, United States Geological Survey and University of California. Especially, Prof. Idriss, University of California, Davis provided the geologic datas of the site. This paper is appreciably published in responding for their providing useful materials. Dr. Eto, Mr. Ejiri and Mr. Naganuma are appreciated for their consulting work through this project work.

We hope this paper will provide one of useful materials for seismic hazard mitigation practice.

\section{REFERENCES}

1) The Earthquake Engineering Committee : Reconaissance report on the Loma Prieta Earthquake of Oct.17, 1989, 2.2 Analysis on the Damage Features of the Cypress Viaduct Caused by the Loma Prieta Earthquake of 1989, Proc. JSCE, Vol.422/ I -14, Oct. 1990.

2) Caltrans : Log of Test Boring Concerning Cypress Viaduct, 1990.
3) Caltrans : Borehole Velocity Surveys at the Embarcadero in San Francisco and the Cypress Structure in Oakland, August 1990.

4) Seed, H.B., et al. : Implication of Site Effects in the Mexico City Earthquake of Sept. 1985 for Earthquake Resistant Design Criteria in the San Fransisco Bay Area of California, UCB/EERC-89/03, Mar. 1989.

5) Helly, E.J., et al. : Flatland Deposits of the San Francisco Bay Region, California-Their Geology and Engineering Properties, and Their Importance to Comprehensive Planning, Geological Survey Professional Paper 943.

6) Ohmachi, T., et al. : Ground Motion Characteristics in the San Francisco Bay Area Detected by Microtremor Measurements - A Preliminary Assesments, Tokyo Institute of Technology, No.800104, Nov.30, 1989.

7) Nims, D.K., et al. : Collapse of the Cypress Street Viaduct as a Result of the Loma Prieta Earthquake, UCB/EERC89/16, Nov.1989.

8) Moehle, J.P. and Mahin, S.A. : Implications of Nondestructive and Destructive Tests on the Cypress Street Viaduct Structure, 7th US-Japan workshop on Bridge Structure, UJNR, May 1990.

9) Housner, G.W., et al. : Competing Against Time, Report to Governor George Deukmejian from the Governor's Board of Inquiry on the 1989 Loma Prieta Earthquake, May 1990.

10) Darwin, D. and Pecknold, D.A. : Inelastic Model for Cyclic Biaxial Loading of Reinforced Concrete, Civil Eng. Studies, Structural Series, No.409, Univ. of Illinois, Urbana-Champaign, Illinois, July 1974.

11) Caltrans : As Built Plans, 10th to Distribution Structures, July 26, 1957.

12) Takeda, T., et al. : Reinforced Concrete Response to Simulated Earthquakes, Jour. Structural Div., ASCE, Vol.96, No.ST12, pp.2557 2573, 1970.

13) Caltrans : Cypress Street Viaduct Bent 45, 46 and 47 Retrofit Detail - As Built Drawing, Dec. 1989.

14) Park, R. and Paulay, T. : Reinforced Concrete Structures, John Wiley \& Sons, pp.407 410, 1975.

15) Applied Technology Council : Seismic Design Guideline for Highway Brides, 2nd Printing, June 1986.

(Received June 27, 1991)

サイプレス高架橋の崩壊と補強後橋脚の耐震性に関する

一考察

\section{大内 - - 松田 隆・後藤洋三}

1989 年ロマプリエ夕地震でのサイプレス高架橋の被災と, 補強後橋脚の耐震性を数 值解析により検討した。橋脚の破壊と損傷程度は，地盤条件と橋脚構造夕イプに深い因 果関係を持つと予想され, 最初の解析はその一連のシナリオに定量的説明を加えること を目的とする．また第 2 の解析は補強後橋脚の合衆国現行設計レベルの地震に対する而 震性を検討することを目的とする. 